\title{
Trichostrongylus colubriformis affecting sheep phosphorus metabolism and precision feeding as a mitigating strategy
}

\author{
Trichostrongylus colubriformis afetando o metabolismo do fosforo em ovinos e \\ alimentação de precisão como estratégia de mitigação
}

Tairon Pannunzio Dias-Silva1* (1D; Helder Louvandini²; Alessandro Francisco Talamini do Amarante ${ }^{3}$

${ }^{1}$ Universidade Federal do Piauí - UFPI, Campus "Professora Cinobelina Elvas”, Bom Jesus, PI, Brasil

${ }^{2}$ Laboratório de Nutrição Animal, Centro de Energia nuclear na Agricultura - CENA, Universidade de São Paulo - USP, Piracicaba, SP, Brasil

${ }^{3}$ Instituto de Biociências, Universidade Estadual Paulista - UNESP, Botucatu, SP, Brasi

How to cite: Dias-Silva TP, Louvandini H, Amarante AFT. Trichostrongylus colubriformis affecting sheep phosphorus metabolism and precision feeding as a mitigating strategy. Braz J Vet Parasito/ 2021; 30(1): e026820. https://doi.org/10.1590/S1984-29612021001

\begin{abstract}
This review details the negative effects of Trichostrongylus colubriformis infection in sheep phosphorus metabolism and direct and indirect impacts from high excretion from susceptible animals, as well as the advantages offered by precision feeding as potential strategies to mitigate loss. In sheep infected with $T$. colubriformis there is a high reduction in $\mathrm{P}$ bioavailability, because of depression in the absorptive capacity of this mineral, affecting the absorption and recycling of $\mathrm{P}$ to the digestive tract, causing mineral deficiency. Therefore, precision feeding compiles animal genetics information, feeding type and grazing management to control animal feed intake and quantity and quality of manure produced. In this sense, the adoption of precision feeding can provide a better arrangement of the information, making sheep production more economically, socially and environmentally sustainable.
\end{abstract}

Keywords: Mitigation strategy, parasitism, phosphorus metabolism.

\section{Resumo}

Essa revisão detalha os efeitos negativos da infecção por Trichostrongylus colubriformis no metabolismo do fósforo de ovinos e os impactos diretos e indiretos da alta excreção em animais susceptíveis, bem como as vantagens oferecidas pela alimentação de precisão como estratégia potencial para mitigar perdas. Em ovinos infectados com T. colubriformis, há uma alta redução na biodisponibilidade de $\mathrm{P}$, devido à depressão na capacidade de absorção desse mineral, afetando a absorção e a reciclagem de $\mathrm{P}$ no trato digestivo, causando deficiência mineral. Portanto, a alimentação de precisão compila informações de genética animal, tipo de alimentação e manejo da pastagem para controlar o consumo de alimento e a quantidade e qualidade dos dejetos produzidos. Nesse sentido, a adoção da alimentação de precisão pode proporcionar um melhor arranjo das informaç̃̃es, tornando a produção de ovinos mais econômica, social e ambientalmente sustentável.

Palavras-chave: Estratégia de mitigação, parasitismo, metabolismo do fósforo. 


\section{Introduction}

Phosphorus $(P)$ is one of the most important nutrients of animal nutrition, acting on the various metabolic processes of the body, aiming at homeostasis (Goselink et al., 2015). Also, P is one of the main components of the bones and it is essential part of the nucleic acids (deoxyribonucleic and ribonucleic acids), being indispensable for the transference of genetic information. In ruminants, $P$ plays also an important role in the metabolism, maintenance and growth of the rumen microbiota (Breves \& Schröder, 1991; Pfeffer et al., 2005).

Because $\mathrm{P}$ is essential component in the ruminant diet, its deficiency is known and economically important worldwide. Being considered a limiting mineral, the correct balancing of $\mathrm{P}$ in the diet promotes better animal performance and reduce the costs with supplementation (Diaz Gonzalez et al., 1998).

It is very important to maximize $P$ efficiency, because the sources of $P$ used for feed and other are not infinite. In the ruminant production, the efficiency of $P$ utilization ( $P$ in animal product leaving the farm as $\%$ of total $P$ inputs at farm gate) varies substantially, mainly due to the lack of knowledge about the true nutritional requirement, assimilative capacity by animals related to conditions of nutrition and health (Goselink et al., 2015).

In ruminant production, commonly, the gastrointestinal parasitism and its effects impact not only the animal performance but also, directly and indirectly the environment. In sheep, Trichostrongy/us colubriformis infection impairs the true absorption of phosphorus, the true availability, promoting high faecal P excretion of dietary origin (Silva et al., 2018). However, new technologies are being developed aiming to determine the best level of nutrients requirements and, consequently, to reduce the possible negative impacts of animal manure on environment such as precision feeding that is based on proper evaluation of the nutritional potential of feed ingredients, in the precise determination of nutrient requirements and in the formulation of balanced diets that limit the amount of excess nutrients (Pomar et al., 2014).

In order to encompass this complex process of animal production and environment (causes and consequences), the aim of this review is to assess, through the analysis of the published literature, the effects of parasitism by T. colubriformis on sheep phosphorus metabolism and precision feeding as a mitigating strategy.

\section{Effects of the Parasitism by Trichostrongylus colubriformis}

\section{Clinical signs and effects}

Clinical symptom in infected sheep is the result of interactions between three main drivers, larval challenge (daily number of infective larvae ingested) versus establishment (number of established parasites in the gastrointestinal tract) and immune response (efficiency of host immune response) (Amarante, 2015). As consequence of the efficiency of the host's immune response being influenced by several factors such as rate of infection, time of exposure, genetics and nutrition, it is commonly seen that a herd presents susceptible animals, which are severely affected, resilient sheep, which are able to maintain productivity even infected and, resistant sheep, in which few parasites can settle. This difference among animals results in the negative binomial distribution pattern of parasites (Stear \& Murray, 1994), with few animals eliminating high number of eggs in the pasture for continuity of the parasite cycle.

When sheep are severely affected by $T$. colubriformis and present severe infection there is the occurrence of severe enteritis. The infection site is the initial third (duodenum) of the small intestine where the parasites form tunnels causing intestinal epithelial erosion with generalized atrophy of villi and microvilli, hypertrophy of intestinal crypts, mucosal thickening, and the formation of leukocyte inflammatory infiltrates (Barker, 1973, 1975a; Taylor et al., 2010; Cardia et al., 2011). The nematodes feed on the contents of necrotic epithelial cells (Andronicos et al., 2012), tissue fluid and chyme present in the lumen of the small intestine.

These changes promote increased vascular permeability (Barker, 1975b) impairing gastrointestinal motility with reduced nutrient intake (Greer et al., 2005), with alteration of the flow of digesta along the tract, with reduction of digestion and absorption of nutrients (Coop \& Angus, 1975; Sykes \& Coop, 1976; Steel et al., 1980; Gregory et al., 1985; Cantacessi et al., 2010) and, consequent reduction of the growth rate (Steel et al., 1980).

Literature data are controversial regarding the cause of decreased productivity in sheep infected with T. colubriformis. Studies have pointed to parasite-induced anorexia as the cause of productive losses (Brown et al., 1989; Fox, 1997; Cantacessi et al., 2010). However, this mechanism responsible for anorexia still remains undefined. Another line of research attributes to low efficiency in digestion and nutrient absorption by infected sheep as a cause of low productivity (Coop \& Kyriazakis, 1999; Cardia et al., 2011). The decrease in utilization of nutrients results 
from both non-use (due to the reduction of the absorptive capacity) and partitioning of absorbed nutrients, which would be used to maximize animal performance. Thus, with the establishment of the infection, the nutrients are directed towards the repair of the gastrointestinal tract, replacement of proteins lost as a result of damage to the intestinal mucosa (Taylor et al., 2010), as well as enhancement of host immune response (Coop \& Sykes, 2002).

Trichostrongylus colubriformis usually has subclinical characteristics, causing slow body development, loss in weight, reduction in meat and wool production, and increased expenses associated with disease control (Abrão et al., 2010). However, it is emphasized that few animals with high parasite load (susceptible animals) may compromise the production system due to the reinfection as well as may cause environmental risks.

\section{Influence on phosphorus metabolism}

Effects of parasitism on phosphorus (P) metabolism in sheep can lead to serious damage to bone growth and animal performance (Sykes \& Coop, 1976; Sykes et al., 1977). Poppi et al. (1985) evaluating sheep infected with a daily dose of 2500 larvae of $T$. colubriformis during 14 weeks found that the infection affected various aspects of $P$ metabolism such as reduction concentration of this element in blood, reduced feed intake and impairment capacity of $\mathrm{P}$ absorption. These authors also found high duodenal flow of $\mathrm{P}$ indicating a greater amount of recycling $\mathrm{P}$ via saliva. In addition, high ileum flow of $\mathrm{P}$ was observed, indicating that due effects of the infection, the duodenal capacity of absorption has been compromised, changing the usual route of $\mathrm{P}$ absorption to the ileum.

Lower levels of $\mathrm{P}$ in the bones of sheep infected with T. colubriformis was found when compared to sheep pair-fed or fed ad libitum (Sykes et al., 1975; Sykes \& Coop, 1976), possibly due to a reduced capacity of nutrient absorption (Reveron et al., 1974; Sykes \& Coop, 1976; Brown et al., 1989; Fox, 1997) induced by T. colubriformis (Barker, 1973, 1975a; Taylor et al., 2010; Cardia et al., 2011).

According to Wilson \& Field (1983), the reason for this effect is that T. colubriformis induces a mineral deficiency by reducing the absorption of dietary $\mathrm{Ca}$ and $\mathrm{P}$, and/or increasing endogenous loss of these macro elements. The authors also found that sheep infected with a daily dose of 3000 larvae of $T$. colubriformis during 8 weeks present a $30 \%$ reduction on exogenous $\mathrm{P}$ absorption and increased endogenous loss, causing $\mathrm{P}$ deficiency. In this way, there was a reduction on $\mathrm{P}$ secretion via saliva as well as a reduction concentration of this element in plasma (Wilson \& Field, 1983).

There are few studies evaluating P supplementation in sheep infected with gastrointestinal parasites and the effects on absorption capacity and availability of this element on animal tissues. However, Coop \& Field (1983) showed that a higher inclusion of $\mathrm{P}$ in sheep diets $(2.75 \mathrm{~g} \mathrm{P} / \mathrm{kg}$ ) promoted a greater live weight gain in sheep receiving a daily dose of $2500 \mathrm{~L}_{3}$ larvae. Phosphorus supplementation also reduced fecal egg counts and the parasite load, suggesting that $\mathrm{P}$ level in the diet may interfere with the development of resistance during a continuous infection.

\section{Precision Feeding as a Mitigation Strategy of Phosphorus Excretion from Sheep with High Worm Burdens}

Animal production utilizes P inefficiently, with excretion rate of 60 to $80 \%$ of that ingested (Knowlton et al., 2004). The phosphorus that enters the farms via feed is little used, metabolized for the production of meat, milk or wool by the animals and consequently remains in the farms as manure. In this scenario, practical feeding recommendations influence $P$ intakes by animals and inconsistent recommendations from nutritionists, veterinarians and extension personnel have led many farmers to feed $P$ in excess of the NRC recommendations. However, should be emphasized that the nutritional recommendations programs such as NRC, ARC, CSIRO, AFRC, INRA use a variety of information (animals, sex, feed, breed, productive capacity, physiological stage and environmental conditions) of a regional character that often does not reflect the reality of other scenarios around the world. The management adopted, the $\mathrm{P}$ status in soil and geographic location may lead to a wide range of dietary $\mathrm{P}$ contents and amounts of $\mathrm{P}$ offered (Vitti \& Kebreab, 2010). This means either that large safety margins have been used during the development of some of these systems or that there is still not much consensus about the actual P ruminant requirements according to physiological stages and production levels of certain characteristics (Vitti \& Kebreab, 2010).

According to study conducted by Pfeffer et al. (2005), the maintenance requirement of $P$ is about $1 / 3-1 / 2$ of the total dietary $P$ requirement of dairy cow. Thus, knowledge about the phosphorus flows in ruminants ( $P$ intake, digestion, absorption and availability) will improve efficiency of $\mathrm{P}$ utilization, reducing $\mathrm{P}$ excretion and minimizing the imbalance not only of P but also of $\mathrm{N}$ in manure (Knowlton et al., 2004). 
Over the years, new technologies has been developed which are been applied to obtain sustainability of livestock farms entitled as Precision Livestock Farming (PLF) (Berckmans, 2004). This methodology is defined as the collection and use of information via communication technological for improved control of fine-scale animal and physical resource variability to optimize economic, social, and environmental dairy farm performance (Eastwood et al., 2012). This process involves the continuous, automatic monitoring of animal welfare, health, production and environmental impact in real-time (Berckmans, 2007), aiming to increase animal production in quality and quantity in a sustainable way.

An important PLF that can improve sheep production system and to reduce the direct (Guerci et al., 2013) and indirect (Tullo et al., 2019) effects of P on environment is the precision feeding (PF) (Tullo et al., 2019), which consists in to get the exact nutrient to the right animal at the correct time (Pomar et al., 2014) and at the right quantities. This practice can be conducted by controlling of individual feed intake, the amount and composition of manure produced and the associated emissions from manure (Guerci et al., 2013). The technology based on PF uses information such as animal genetics, feeding type and grazing management. For this, it requires advanced and precise technology to evaluate the nutritional requirements of animals, production and management of pastures (Shields \& Orme-Evans, 2015; Tullo et al., 2019).

With the objective of the best use, availability and control of the phosphorus some techniques are reported: multiphase feeding, use of feed additives which reduce the total excreted phosphorus, use of highly digestible inorganic phosphates for partial replacement of conventional sources of phosphorus in feed (Tullo et al., 2019). In ruminant production another question that can be inserted in the concept of maximum animal production is the real effect of worm infestation that undoubtedly and negatively impacts some animals (susceptible animals) of the herd (in the case of $T$. colubriformis the most of present subclinical symptoms), promoting changes in digestibility and P metabolism, which will invariably be excreted in the faeces.

Precision feeding technology can be a watershed for the beginning of a new path for the development of strategies capable of reducing, significantly, the $P$ excretion via faeces from the susceptible animals infected by T. colubriformis. Strategies that either can be formed via new techniques or gather information from pre-existing techniques should be used as a mitigation strategy of phosphorus excretion.

Among the pre-existing techniques, we can cite the use and/or construction of biomathematical models using data provided by the isotopic dilution technique, which precisely provide data on the metabolism of the element in the animal organism (Bravo et al., 2003; Vitti \& Kebreab 2010; Silva et al., 2018) subsidizing the precision feeding technology, with control of the true nutritional requirement of the nutrient by the animal as well as manure management from these animals. This technique becomes a tool that can give more robustness to precision feeding by providing true availability of nutrients, in particular case, those with potential negative effect when excreted by faeces is the use of biomathematical models by the isotopic dilution technique. The use of these techniques aims directly to determine, with precision, the nutritional requirements of $\mathrm{P}$ in sheep subsidizing the correct $\mathrm{P}$ supplementation under grazing conditions, reducing overfeeding, reducing P content of excreta and production costs. However, more research is needed to verify the effectiveness of PF in sheep production, in the control of gastrointestinal nematodes, in the correct determination of nutritional requirements and finally, as a mitigating strategy.

\section{Final Comments}

The essentiality of phosphorus in the animal organism is demonstrated by its role as the nutrient with the highest number of metabolic functions, acting at all physiological stages, productive and reproductive. Due to this, their participation in the ruminant diet is mandatory.

Failure to determine the correct phosphorus requirement leads to over-supply of this nutrient causing negative impacts to the production system (overfeeding and high production costs).

Trichostrongylus colubriformis infection is a negative and important factor that alters the $\mathrm{P}$ metabolism of susceptible animals affecting the absorptive capacity, both of the dietary and endogenous fractions of phosphorus, in which it is excreted via faeces. Thus, further researches are needs to clarify more precisely which $\mathrm{P}$ recommendation is necessary under certain farming conditions or a certain physiological state of the sheep, aiming not only to meet nutritional requirements but also to reduce phosphorus loss through manure.

For this, the adoption of precision feeding in the support of management strategies, can lead to the reduction of farms production costs. Precision feeding aims to ensure intake control, the amount and composition of manure 
and risks associated with emissions from manure. Finally, it is essential to apply the technology to the understanding of the interaction between animal production and the environment, seeking sustainable development with respect to the environment, ecologically balanced production and economically viable.

\section{References}

Abrão DC, Abrão S, Viana CHC, Valle CR. Utilização do método Famacha no diagnóstico clínico individual de haemoncose em ovinos no sudoeste do Estado de Minas Gerais. Rev Bras Parasitol Vet 2010; 19(1): 68-70. http://dx.doi.org/10.1590/S198429612010000100014. PMid:20385064.

Amarante AFT. Os parasitas de ovinos. 1. ed. São Paulo: Editora Unesp; 2015.

Andronicos NM, McNally J, Kotze AC, Hunt PW, Ingham A. Trichostrongylus colubriformis larvae induce necrosis and release of IL33 from intestinal epithelial cells in vitro: implications for gastrointestinal nematode vaccine design. Int J Parasitol 2012; 42(3): 295-304. http://dx.doi.org/10.1016/j.jpara.2012.01.007. PMid:22366550.

Barker IK. Scanning electron microscopy of the duodenal mucosa of lambs infected with Trichostrongylus colubriformis. Parasitology 1973; 67(3): 307-314. http://dx.doi.org/10.1017/S0031182000046539. PMid:4761770.

Barker IK. Intestinal pathology associated with Trichostrongylus colubriformis infection in sheep: histology. Parasitology 1975a; 70(2): 165-171. http://dx.doi.org/10.1017/S0031182000049623. PMid:1128919.

Barker IK. Intestinal pathology associated with Trichostrongylus colubriformis infection in sheep: vascular permeability and ultrastructure of the mucosa. Parasitology 1975b; 70(2): 173-180. http://dx.doi.org/10.1017/S0031182000049635. PMid:1128920.

Berckmans D. Automatic monitoring of animal by precision livestock farming. In: Madec F, Clement G, editors. Animal production in Europe: the way forward in a changing world. Saint-Malo, France: International Society for Animal Hygiene; 2004. p. 27-31.

Berckmans D. Precision livestock farming. Comput Electron Agric 2007; 63(1): 1. http://dx.doi.org/10.1016/j.compag.2007.09.002.

Brown MD, Poppi DP, Sykes AR. The effects of a concurrent infection of Trichostrongylus colubriformis and Ostertagia circumcincta on calcium, phosphorus and magnesium transactions along the digestive tract of lambs. J Comp Pathol 1989; 101(1): 11-20. http:// dx.doi.org/10.1016/0021-9975(89)90072-8. PMid:2794148.

Bravo D, Sauvant D, Bogaert C, Meschy F 3rd. Quantitative aspects of phosphorus excretion in ruminants. Reprod Nutr Dev 2003; 43(3): 285-300. http://dx.doi.org/10.1051/rnd:2003021. PMid:14620634.

Breves G, Schröder B. Comparative aspects of gastrointestinal phosphorus metabolism. Nutr Res Rev 1991; 4(1): 125-140. http:// dx.doi.org/10.1079/NRR19910011. PMid:19094328.

Cantacessi C, Mitreva M, Campbell BE, Hall RS, Young ND, Jex AR, et al. First transcriptomic analysis of the economically important parasitic nematode, Trichostrongylus colubriformis, using a next-generation sequencing approach. Infect Genet Evol 2010; 10(8): 1199-1207. http://dx.doi.org/10.1016/j.meegid.2010.07.024. PMid:20692378.

Cardia DFF, Rocha-Oliveira RA, Tsunemi MH, Amarante AFT. Immune response and performance of growing Santa Ines lambs to artificial Trichostrongy/us colubriformis infections. Vet Parasitol 2011; 182(2-4): 248-258. http://dx.doi.org/10.1016/j. vetpar.2011.05.017. PMid:21641720.

Coop RL, Angus KW. The effect of continuous doses of Trichostrongylus colubriformis larvae on the intestinal mucosa of sheep and on liver vitamin A concentration. Parasitology 1975; 70(1): 1-9. http://dx.doi.org/10.1017/S0031182000048800. PMid:1118182.

Coop RL, Field AC. Effect of phosphorus intake on growth rate, food intake, and quality of the skeleton of growing lambs infected with the intestinal nematode Trichostrongylus vitrinus. Res Vet Sci 1983; 35(2): 175-181. http://dx.doi.org/10.1016/S00345288(18)32176-3. PMid:6635343.

Coop RL, Kyriazakis I. Nutrition-parasite interaction. Vet Parasito/ 1999; 84(3-4): 187-204. http://dx.doi.org/10.1016/S03044017(99)00070-9. PMid:10456415.

Coop RL, Sykes AR. Interactions between gastrointestinal parasites and nutrients. In: Freer M, Dove H, editors. Sheep nutrition. Melbourne: CSIRO Publishing; 2002. p. 313-331. http://dx.doi.org/10.1079/9780851995953.0313.

Diaz Gonzalez FH, Ospina H, Barcellos JOJ. Nutrição mineral em ruminantes. 2. ed. Porto Alegre: Editora da UFRGS; 1998.

Eastwood CR, Chapman DF, Paine MS. Networks of practice for co-construction of agricultural decision support systems: case studies of precision dairy farms in Australia. Agric Syst 2012; 108: 10-18. http://dx.doi.org/10.1016/j.agsy.2011.12.005.

Fox MT. Pathophysiology of infection with gastrointestinal nematodes in domestic ruminants: recent developments. Vet Parasitol 1997; 72(3-4): 285-308. http://dx.doi.org/10.1016/S0304-4017(97)00102-7. PMid:9460203. 
Goselink RMA, Klop G, Dijkstra J, Bannink A. Phosphorus metabolism in dairy cattle: literature study on recent developments and gaps in knowledge. Wageningen: Wageningen UR Livestock Research; 2015. (Livestock Research rapport; no. 910).

Greer AW, Stankiewicz M, Jay NP, McAnulty RW, Sykes AR. The effect of concurrent corticosteroid-induced immuno-suppression and infection with the intestinal parasite Trichostrongylus colubriformis on feed intake and utilization in both immunologically naïve and competent sheep. Anim Sci 2005; 80(1): 89-99. http://dx.doi.org/10.1079/ASC41100089.

Gregory PC, Wenham G, Poppi D, Coop RL, MacRae JC, Miller SJ. The influence of a chronic subclinical infection of Trichostrongylus colubriformis on gastrointestinal motility and digesta flow in sheep. Parasitology 1985; 91(2): 381-396. http://dx.doi.org/10.1017/ S0031182000057449. PMid:4069755.

Guerci M, Knudsen MT, Bava L, Zucali M, Schönbach P, Kristensen T. Parameters affecting the environmental impact of a range of dairy farming systems in Denmark, Germany and Italy. J Clean Prod 2013; 54(1): 133-141. http://dx.doi.org/10.1016/j. jclepro.2013.04.035.

Knowlton KF, Radcliffe JS, Novak CL, Emmerson DA. Animal management to reduce phosphorus losses to the environment. J Anim Sci 2004; 82(Suppl 13): E173-E195. http://dx.doi.org/10.2527/2004.8213_supplE173x. PMid:15471797.

Pfeffer E, Beede DK, Valk H. Phosphorus metabolism in ruminants and requirements of cattle. In: Pfeffer E, Hristov AN, editors. Nitrogen and phosphorus nutrition in cattle. Wallingford: CAB International; 2005. p. 195-231. http://dx.doi.org/10.1079/978085 1990132.0195.

Pomar C, Pomar J, Dubeau F, Joannopoulos E, Dussault JP. The impact of daily multiphase feeding on animal performance, body composition, nitrogen and phosphorus excretions, and feed costs in growing-finishing pigs. Animal 2014; 8(5): 704-713. http:// dx.doi.org/10.1017/S1751731114000408. PMid:24739349.

Poppi DP, MacRae JC, Brewer AC, Dewey PJ, Walker A. Calcium and phosphorus absorption in lambs exposed to Trichostrongylus colubriformis. J Comp Pathol 1985; 95(3): 453-464. http://dx.doi.org/10.1016/0021-9975(85)90050-7. PMid:4031139.

Reveron AE, Topps JH, Gelman AL. Mineral metabolism and skeletal development of lambs affected by Trichostrongylus colubriformis. Res Vet Sci 1974; 16(3): 310-319. http://dx.doi.org/10.1016/S0034-5288(18)33729-9. PMid:4368917.

Shields S, Orme-Evans G. The impacts of climate change mitigation strategies on animal welfare. Animals 2015; 5(2): 361-394. http://dx.doi.org/10.3390/ani5020361. PMid:26479240.

Silva TPD, Jimenez CR, leda EH, Abdalla AL, Louvandini H. Phosphorus kinetics in lambs experimentally infected with Trichostrongylus colubriformis with the use of ${ }^{32}$ P. Exp Parasito/ 2018; 188: 13-20. http://dx.doi.org/10.1016/j.exppara.2018.03.011. PMid:29555416.

Stear MJ, Murray M. Genetic resistance to parasitic disease: particularly of resistance in ruminants to gastrointestinal nematodes. Vet Parasito/ 1994; 54(1-3): 161-176. http://dx.doi.org/10.1016/0304-4017(94)90089-2. PMid:7846849.

Steel JW, Symons LEA, Jones WO. Effects of level of larval intake on the productivity and physiological and Metabolic responses of lambs infected with Trichostrongylus colubriformis. Aust J Agric Res 1980; 31(4): 821-838. http://dx.doi.org/10.1071/AR9800821.

Sykes AR, Coop RL. Intake and utilization of food by growing lambs with parasitic damage to the small intestine caused by daily dosing with Trichostrongylus colubraformis larvae. J Agric Sci 1976; 86(3): 507-515. http://dx.doi.org/10.1017/S0021859600061049.

Sykes AR, Coop RL, Angus KW. Experimental production of osteoporosis in growing lambs by continuous dosing with Trichostrongylus colubriformis larvae. J Comp Pathol 1975; 85(4): 549-559. http://dx.doi.org/10.1016/0021-9975(75)90122-X. PMid:1237505.

Sykes AR, Coop RL, Angus KW. The influence of chronic Ostertagia circumcincta infection on the skeleton of growing sheep. $J$ Comp Pathol 1977; 87(4): 521-529. http://dx.doi.org/10.1016/0021-9975(77)90058-5. PMid:591651.

Taylor MA, Coop RL, Wall RL. Parasitologia veterinária. 3. ed. Rio de Janeiro: Guanabara Koogan; 2010.

Tullo E, Finzi A, Guarino M. Review: environmental impact of livestock farming and precision livestock farming as a mitigation strategy. Sci Total Environ 2019; 650(2): 2751-2760. http://dx.doi.org/10.1016/j.scitotenv.2018.10.018. PMid:30373053.

Vitti DMSS, Kebreab E. Phosphorus and calcium utilization and requirements in farm animals. London: CAB International; 2010. http://dx.doi.org/10.1079/9781845936266.0000.

Wilson WD, Field AC. Absorption and secretion of calcium and phosphorus in the alimentary tract of lambs infected with daily doses of Trichostrongylus colubriformis or Ostertagia circuncincta larvae. J Comp Pathol 1983; 93(1): 61-71. http://dx.doi. org/10.1016/0021-9975(83)90043-9. PMid:6841694. 